\title{
Ceratomyxa bohari sp. n. (Myxozoa: Ceratomyxidae) from the gall bladder of Lutjanus bohar Forsskål from the Red Sea coast off Saudi Arabia: morphology, seasonality and SSU rDNA sequence
}

\author{
Lamjed Mansour ${ }^{1,2}$, Abdel-Azeem S. Abdel-Baki ${ }^{1,3}$, Ahmad F. Tamihi ${ }^{1}$ and Saleh Al-Quraishy ${ }^{1}$ \\ ${ }^{1}$ Zoology Department, College of Science, King Saud University, Riyadh, Saudi Arabia; \\ ${ }^{2}$ Unité de Recherche de Biologie intégrative et Ecologie évolutive et Fonctionnelle des Milieux Aquatiques, Département de \\ Biologie, Faculté des Sciences de Tunis, Université de Tunis El Manar, Tunisia; \\ ${ }^{3}$ Zoology Department, Faculty of Science, Beni-Suef University, Egypt
}

\begin{abstract}
A new myxozoan, Ceratomyxa bohari sp. n., infecting the gall bladder of two-spot red snapper, Lutjanus bohar Forsskål, in the Red Sea off Saudi Arabia, is described using light microscopy and characterised genetically. The infection was recorded as mature spores floating free in the bile. The overall prevalence of infection of the type host was 19\% (67 fish infected of 360 examined), with the highest prevalence in autumn $(31 \% ; 28 / 90)$ and the lowest in winter at $12 \%(11 / 90)$. Mature spores are slender and slightly crescent-shaped in the frontal view, with anterior and posterior margins tapered gradually to rounded valvular tips. Spore valves are unequal with a prominent sutural line. The spore dimensions are 3-4 $\mu \mathrm{m}$ (mean $3.5 \mu \mathrm{m})$ in length and 16-19 $\mu \mathrm{m}$ (mean $17 \mu \mathrm{m})$ in thickness. Two polar capsules are spherical, equal in size, $1.5 \mu \mathrm{m}$ in diameter. Coils of the polar filament are indiscernible. The sporoplasm is binucleated and fills nearly one third of the extracapsular space restricted to the area below the capsules. The molecular analysis based on the small subunit rDNA (SSU rDNA) sequence revealed a close relationship with majority of species of Ceratomyxa Thélohan, 1892 and phylogenetic clustering with species from different geographical location. Thus, the shorter spore of the present Ceratomyxa species and the divergence of the SSU rDNA sequences were the distinctive features that separate it from all previously described species and identified this parasite as a new species of Ceratomyxa.
\end{abstract}

Keywords: Myxosporea, fish parasites, Bivalvulida, spore, coelozoic infection, phylogeny, Lutjanidae

Members of the myxozoan genus Ceratomyxa Thélohan, 1892 are predominantly parasites of the gall bladder of teleosts and elasmobranchs (Gunter et al. 2009). Species of Ceratomyxa have elongated, generally crescent-shaped or arcuate, sometimes subspherical or ovoid, spores. Shell valves are frequently conical or subhemispherical and exceed significantly in length one half of the axial diameter of the spore (Gunter et al. 2010). Since the establishment of Ceratonova Atkinson, Foott et Bartholomew, 2014, which includes C. shasta (Noble, 1950) (syn. Ceratomyxa shasta Noble, 1950) and Ceratonova gasterostea Atkinson, Foott et Bartholomew, 2014 (see Atkinson et al. 2014), all species accommodated in Ceratomyxa are coelozoic and occur in the gall bladder of marine teleost fish.

All Ceratomyxa species with known SSU rDNA sequences cluster in the single large clade within the marine myxosporean lineage (Gunter et al. 2009, Fiala et al. 2015). Although this clade contains more than 70 species of $\mathrm{Cer}$ atomyxa, the presence of Palliatus indecorus Shulman,
Kovaleva et Dubina, 1979 and Myxodavisia bulani Fiala, Hlavničková, Kodádková, Freeman, Bartošová-Sojková et Atkinson, 2015 caused the paraphyletic character of the Ceratomyxa clade (Fiala et al. 2015, Rocha et al. 2015).

The fish genus Lutjanus Bloch contains 70 species and a review of the available literature revealed that this genus is known to be infected with seven myxozoan species belonging to four genera. These species are Kudoa hypoepicardialis Blaylock, Bullard et Whipps, 2004; Kudoa lutjanus Wang, Huang, Tsai, Cheng, Tsai, Chen, Chen, Chiu, Liaw, Chang et Chen, 2005; Kudoa lemniscati Miller et Adlard, 2012; Unicapsula andersenae Miller et Adlard, 2013; Sphaerospora motemarini Holzer, Pecková, Patra, Brennan, Yanes-Roca et Main, 2013 and Henneguya jocu Azevedo, Rocha, Matos, Matos, Oliveira, Al-Quraishy et Casal, 2014 (see Miller and Adlard 2013, Azevedo et al. 2014, Holzer et al. 2013). To our knowledge, however, only one Ceratomyxa species has been reported from fish of this genus, namely C. milleri Gunter, Whipps et Adlard, 
2009 described from the gall bladder of Lutjanus fulviflamma Forsskål collected in the Helena Island, Moreton Bay, Queensland, Australia (Gunter et al. 2009).

Although there is considerably exhaustive information on the ceratomyxan parasites from different parts of the world, little is known about the distribution and diversity of species of this genus in the Red Sea fishes. Research on these parasites is restricted to light microscopic description of just five species from the entire extent of the Red Sea coastline, all of which having been described from Egypt: Ceratomyxa ghaffari Ali, Abdel-Baki et Sakran, 2006 from Tylosurus choram Rüppell, C. bassoni Abdel-Ghaffar, Ali, Al Quraishy, Al Rasheid, Al Farraj, Abdel-Baki et Bashtar, 2008 from Plectorhinchus gaterinus Forsskål, C. entzerothi Abdel-Ghaffar, Ali, Al Quraishy, Al Rasheid, Al Farraj, Abdel-Baki et Bashtar, 2008 from Valamugil seheli Forsskål, C. hurghadensis Abdel-Ghaffar, Ali, Al Quraishy, Al Rasheid, Al Farraj, Abdel-Baki et Bashtar, 2008 from Fistularia commersonii Rüppell, and C. swaisi Abdel-Ghaffar, Ali, Al Quraishy, Al Rasheid, Al Farraj, Abdel-Baki et Bashtar, 2008 from Saurida undosquamis Richardson (see Abdel-Ghaffar et al. 2008, Ali et al. 2008).

Here, we describe a new species of Ceratomyxa from the gall bladder of the two-spot red snapper, Lutjanus bohar Forsskål, based on morphological and molecular data. We ascertain the phylogenetic position of this species among congenetic taxa and describe the seasonal variation in prevalence of its infection.

\section{MATERIALS AND METHODS}

A total of 360 specimens of fresh two-spot red snapper, Lutjanus bohar (Teleostei: Lutjanidae), were bought from the fishermen at the boat landing sites of the Red Sea coast off Jizan City in Saudi Arabia. The collection was carried out in a period from April 2013 to April 2014, at a rate of 90 fish per season, of both sexes ranging from $20-40 \mathrm{~cm}$ in length. Upon necropsy, the gall bladder of each specimen was removed and examined for myxosporean infection with light microscopy. Fresh spores were measured and photographed using an Olympus BX51 microscope equipped with an Olympus DP71 camera. Descriptions and measurements of spores followed guidelines of Lom and Arthur (1989). Measurements were based on 30 fresh spores and data were given as range with mean in parentheses. All measurements are in micrometres $(\mu \mathrm{m})$ and drawings were made with the help of a camera lucida. For permanent preparation, air-dried smears were stained with Giemsa after fixation in acetone-free absolute methanol. For DNA analysis, heavily infected gall bladders were preserved in ethanol.

Genomic DNA was extracted from three gall bladders with detected myxosporean infection preserved in $85 \%$ ethanol. After washing three times with phosphate buffer saline solution, extraction was carried using the QIAGEN DNeasy kit (QIAGEN Inc., Valencia, California). The small subunit partial sequence was amplified by PCR using the primers Myxospec F (Fiala 2006) and 18R (Whipps et al. 2003). PCR reactions were performed in a personal thermocycler apparatus (Techne TC-Plus Satellites, Staffordshire, UK) with an initial denaturation at $94^{\circ} \mathrm{C}$ for $5 \mathrm{~min}$, followed by 30 cycles of denaturation at $94^{\circ} \mathrm{C}$ for $20 \mathrm{~s}$, annealing at $52^{\circ} \mathrm{C}$ for $30 \mathrm{~s}$ and extension at $72^{\circ} \mathrm{C}$ for $120 \mathrm{~s}$ with a final extension at $72^{\circ} \mathrm{C}$ for $5 \mathrm{~min}$. Three different positive PCR products from three different individual gall bladders were obtained. These products were then purified and quantified, and sequence reactions were conducted by Macrogen Inc. (Seoul, South Korea). Two additional primers, MYXF1338 and MyxR1437 (Mansour et al. 2013), were also used for sequencing reactions in order to obtain overlapping sequences.

The obtained sequences were assembled and edited using BioEdit version 7.2.5 (Hall 1999). A consensus sequence of 1562 bp was obtained and then used for comparison with previously published sequences through a standard nucleotide-nucleotide BLAST (blastn) (Altschul et al. 1997). Fifty SSU rRNA sequences belonging to species of Ceratomyxa and one sequence of Tetracapsuloides bryosalmonae Canning, Curry, Feist, Longshaw et Okamura, 1999 were extracted from GenBAnk and used for phylogenetic analysis. Alignment was performed using Clustalx 2.1.0.12 software with the default parameters (gap opening penalty of 10 and gap extension penalty of 4 for paired and multiple alignments) (Larkin et al. 2007). Phylogenetic trees were constructed using maximum likelihood (ML), maximum parsimony (MP) and Bayesian inference. ML and MP analyses were conducted in Mega 5.0 software (Tamura et al. 2011) with inferred nodal support based on 1000 bootstrap replicates. ML analysis was performed based on the General Time Reversible model with Gamma distributed rate and Invariant sites $(G T R+G+I)$ selected on the basis of the lowest score of Bayesian Information Criterion and corrected Akaike Information Criterion (AICc) with the MEGA package. Estimates of evolutionary divergence between sequences was conducted in MEGA5 using the Kimura 2-parameter model (Kimura 1980).

For MP, tree was obtained using the Subtree-Pruning-Regrafting algorithm with search level 4 in which the initial trees were obtained by the random addition of sequences (4 replicates). Bayesian analyses were conducted by MrBayes v3.2.5 (Ronquist and Huelsenbeck 2003) under the GTR + I $+\Gamma$ model, selected by Modeltest v. 3.7 (Posada 2008) with parameters setting to 4000000 generations (ngen $=4000000$ ) with 2 runs each containing 4 simultaneous Markov Chain Monte Carlo chains (nchains $=4$ ) and every 100th tree saved (samplefreq $=100$ ). Each run was considered to have reached a stationary distribution based on split frequencies reported in MrBayes and by plotting the log likelihood values (the value 0.009 of the split frequency was reached after 450000 generations). A total of 36667 trees per run were generated. The first $25 \%$ of sampled trees of each Bayesian run were discarded as burnin, the remaining trees in each analysis were used to calculate the posterior probabilities and the final $95 \%$ of trees were used to produce a majority rule consensus tree. Fisher's exact test was carried out to compare prevalences using Quantitative Parasitology web software Version 1.0.9 (Reiczigel et al. 2014). The results were considered significant at $\mathrm{p}<0.05$. 


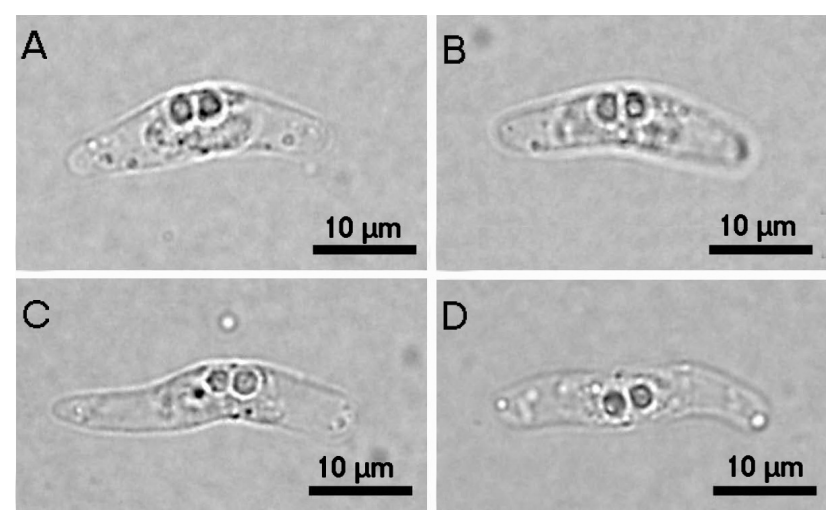

Fig. 1A-D. Fresh spores of Ceratomyxa bohari sp. n. during their movement from the gall bladder of Lutjanus bohar Forsskål.

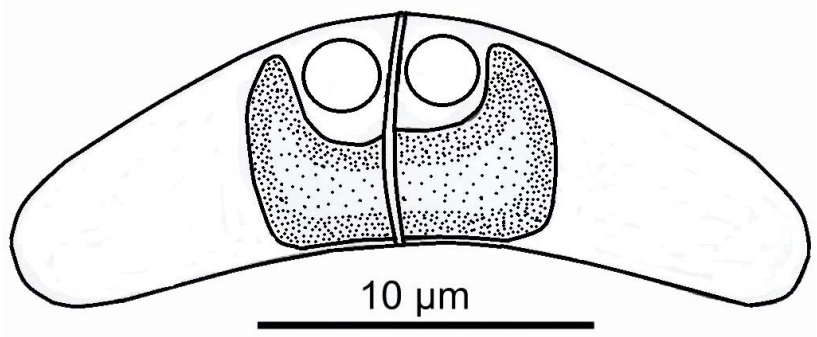

Fig. 2. Schematic drawing of a mature spore of Ceratomyxa bohari sp. n. from the gall bladder of Lutjanus bohar Forsskål.

\section{RESULTS}

Ceratomyxa bohari sp. n.

Figs. 1-3

ZooBank number for species:

urn:lsid:zoobank.org:act:69119BC8-19E3-480A-83AB-DACC630FD6C9

\section{Vegetative stages}

Vegetative stages were not observed. The infection was detected as free mature spores floating in the bile.

\section{Mature spores}

Mature spores slender and slightly crescent-shaped in frontal view, with convex anterior end and slightly bent posterior one (Fig. 1). Anterior and posterior margins tapered gradually terminating in rounded valvular tips (Fig. 1). Spore valves unequal. Sutural line prominent and clearly seen passing between two polar capsules. Spores 3-4 (3.5) long and 16-19 (17) thick. Two polar capsules equal in size, spherical in shape and 1-2 (1.6) in diameter. Polar filament coils indiscernible. Sporoplasm binucleate and nearly filling one third of extracapsular space restricted to area beneath two polar capsules (Fig. 2).

\section{Prevalence and seasonal variation}

Of the 360 examined specimens of Lutjanus bohar, $67(19 \%)$ have gall bladders infected with $C$. bohari. The highest prevalence was observed in autumn, with $31 \%$ fish (28 infected of 90 examined) but the prevalence then declined sharply to $17 \%(15 / 90)$ in spring followed by another decline to $14 \%$ (13/90) in summer, with the lowest

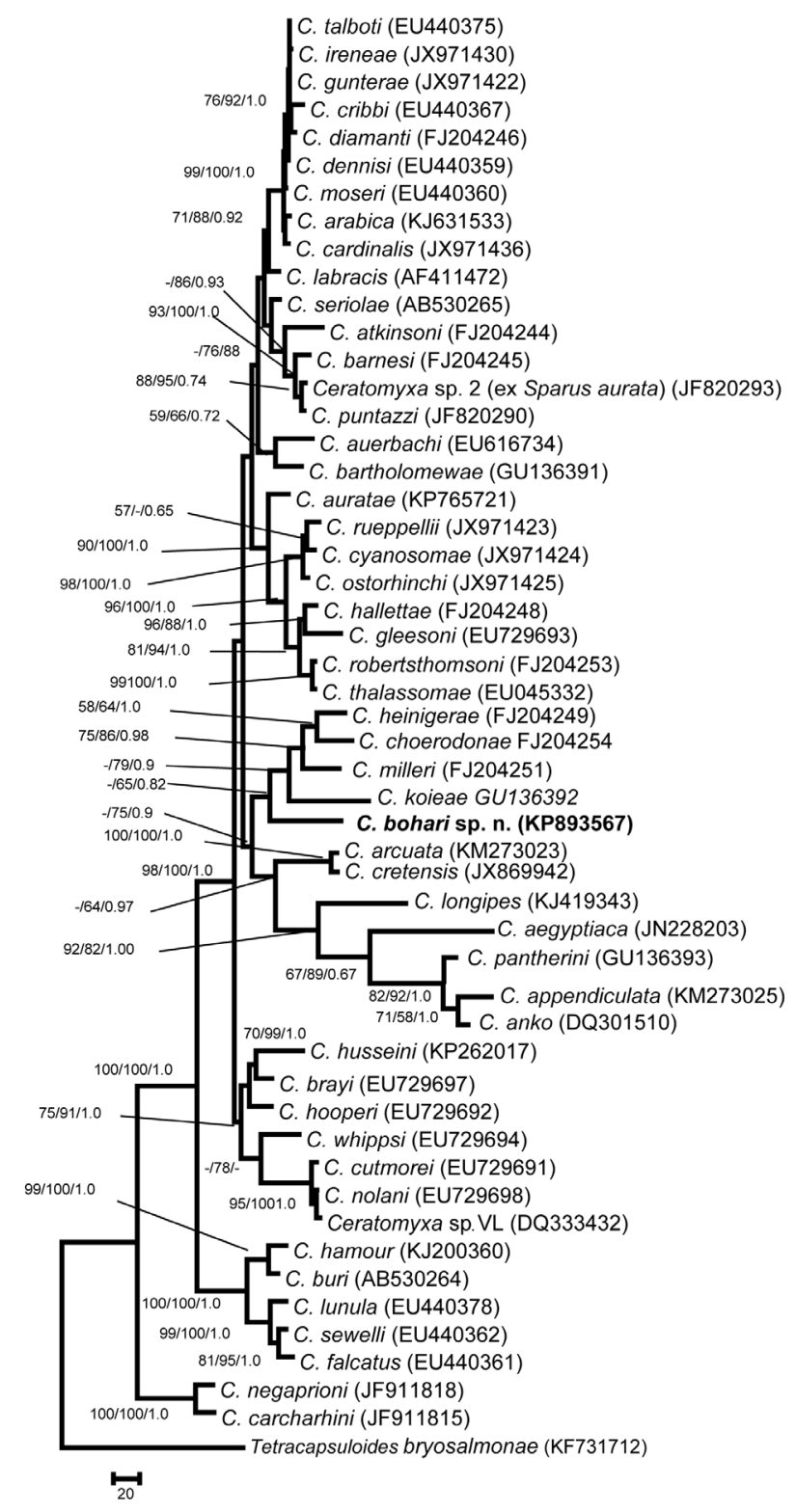

Fig. 3. Phylogenetic tree resulting from Bayesian analysis inferred from the SSU rRNA dataset. Support values at branching nodes are listed as: bootstrap values from maximum likelihood/ bootstrap values from parsimony analyses/Bayesian posterior probabilities from Bayesian analysis. Tetracapsuloides bryosalmonae Canning, Curry, Feist, Longshaw et Okamura, 1999 was used as outgroup. Values below $50 \%$ or not supported by the analysis are indicated by dashes. Scale bar is probability of nucleotide change.

level of $12 \%(11 / 90)$ being recorded in the winter. The data revealed a highly significant seasonal pattern of prevalence $(\mathrm{p}=0.0079)$ fundamentally due to the significant differences between autumn and spring $(\mathrm{p}=0.0352)$, autumn and summer $(\mathrm{p}=0.0123)$ and autumn and winter $(p=0.0034)$ samples; no other significant differences in prevalence were found (all $\mathrm{p}>0.05$ ).

\section{Molecular analysis}

Three partial SSU rRNA gene sequences were obtained from myxozoans in three gall bladders. These sequences were identical and the consensus nucleotide sequence of 
Table 1. Comparative data for Ceratomyxa bohari sp. n. and morphologically similar species (measurements in micrometres).

\begin{tabular}{|c|c|c|c|c|c|c|}
\hline Species & Host & Locality & Spore size & PC size & Spore shape & References \\
\hline $\begin{array}{l}\text { C. anko } \\
\text { Freeman, Yokoyama et } \\
\text { Ogawa, } 2008\end{array}$ & $\begin{array}{l}\text { Lophius litulon } \\
\text { t(Jordan) }\end{array}$ & $\begin{array}{l}\text { Japan } \\
\text { (Pacific Ocean) }\end{array}$ & $\begin{array}{c}9.7-11.9 \times \\
36.9-47.2 \\
(10.8 \times 41.9)\end{array}$ & $\begin{array}{l}\text { 4.1-5.3 (4.6) in } \\
\text { diameter }\end{array}$ & $\begin{array}{l}\text { SP: arcuate to crescent } \\
\text { V: equal with rounded } \\
\text { PC: spherical }\end{array}$ & Freeman et al. 2008 \\
\hline $\begin{array}{l}\text { C. arabica } \\
\text { Al-Qahtani, Man- } \\
\text { sour, Al-Quraishy et } \\
\text { Abdel-Baki, } 2015\end{array}$ & $\begin{array}{l}\text { Acanthopagrus bifasciatus } \\
\text { (Forsskål) }\end{array}$ & $\begin{array}{l}\text { Saudi Arabia } \\
\text { (Arabian Gulf) }\end{array}$ & $\begin{array}{l}7-9 \times 10-14 \\
(8 \times 12)\end{array}$ & $\begin{aligned} 2.5-3.5 & \times 1.5-2.5 \\
(3 & \times 2)\end{aligned}$ & $\begin{array}{c}\text { SP: stubby-shaped } \\
\text { V: unequal } \\
\text { PC: subspherical, } \\
\text { unequal }\end{array}$ & $\begin{array}{l}\text { Al-Qahtani et al. } \\
2015\end{array}$ \\
\hline $\begin{array}{l}\text { C. choerodonae } \\
\text { Heiniger, Gunter et } \\
\text { Adlard, } 2008\end{array}$ & $\begin{array}{l}\text { Choerodon cyanodus } \\
\text { (Richardson) }\end{array}$ & $\begin{array}{l}\text { Heron Island, } \\
\text { Queens land, } \\
\text { Australia }\end{array}$ & $\begin{array}{l}4.2-5.8 \times \\
15.8-26.7 \\
(5 \times 21.4)\end{array}$ & $\begin{array}{c}1.7-2.8 \times 1.4-2.5 \\
(2.2 \times 2)\end{array}$ & $\begin{array}{l}\text { SP: crescent-shaped } \\
\text { V: equal }\end{array}$ & Heiniger et al. 2008 \\
\hline $\begin{array}{l}\text { C. choleospora } \\
\text { Landsberg, } 1993\end{array}$ & $\begin{array}{l}\text { Centropomus undecimalis } \\
\text { (Bloch) }\end{array}$ & $\begin{array}{l}\text { USA } \\
\text { (Atlantic Ocean) }\end{array}$ & $\begin{array}{c}4-5 \times 15-23 \\
(4.5 \times 18.3)\end{array}$ & 2 in diameter & $\begin{array}{c}\text { SP: elongate } \\
\text { V: equal with rounded } \\
\text { ends } \\
\text { PC: circular }\end{array}$ & Landsberg 1993 \\
\hline $\begin{array}{l}\text { C. dissostichi } \\
\text { Brickle, Kalavati et } \\
\text { MacKenzie, } 2001\end{array}$ & $\begin{array}{l}\text { Dissostichus eleginoides } \\
\text { Smitt }\end{array}$ & $\begin{array}{l}\text { Falkland Islands } \\
\text { (Atlantic Ocean) }\end{array}$ & $\begin{array}{c}3.2-4.5 \times \\
15.4-22.8 \\
(3.8 \times 17.8)\end{array}$ & $\begin{array}{c}2.3-3.6 \\
(2.6 \times 1.8)\end{array}$ & $\begin{array}{l}\text { SP: crescent-shaped } \\
\text { V: equal with round } \\
\text { ends }\end{array}$ & Brickle et al. 2001 \\
\hline $\begin{array}{l}\text { C. hamour } \\
\text { Mansour, Al-Qah- } \\
\text { tani, Al-Quraishy et } \\
\text { Abdel-Baki, } 2015\end{array}$ & $\begin{array}{l}\text { Epinephelus coioides } \\
\text { (Hamilton) }\end{array}$ & $\begin{array}{l}\text { Saudi Arabia } \\
\text { (Arabian Gulf) }\end{array}$ & $\begin{array}{c}6-8 \times 15-18 \\
(7 \times 16.5)\end{array}$ & $\begin{array}{l}2-4 \times 3-5 \\
(4 \times 3)\end{array}$ & $\begin{array}{c}\text { SP: crescent shaped } \\
\text { V: equal } \\
\text { PC: pyriform }\end{array}$ & Mansour et al. 2015 \\
\hline $\begin{array}{l}\text { C. heinigerae } \\
\text { Gunter, Whipps et } \\
\text { Adlard, } 2009\end{array}$ & $\begin{array}{l}\text { Choerodon cephalotes } \\
\text { (Castelnau) }\end{array}$ & $\begin{array}{l}\text { Helena Island, } \\
\text { Moreton Bay, } \\
\text { Queensland }\end{array}$ & $\begin{array}{c}16.7-32.3 \times \\
4.8-6.3 \\
(5.6 \times 24)\end{array}$ & $\begin{array}{l}1.8-2.4(2) \\
\text { diameter }\end{array}$ & $\begin{array}{l}\text { SP: crescent-shaped } \\
\text { V: unequal }\end{array}$ & Gunter et al. 2009 \\
\hline $\begin{array}{l}\text { C. husseini } \\
\text { Abdel-Baki, Mansour, } \\
\text { Al-Qahtani, Al Omar } \\
\text { et Al-Quraishy, } 2015\end{array}$ & $\begin{array}{l}\text { Cephalopholis hemistiktos } \\
\text { (Rüppell) }\end{array}$ & $\begin{array}{l}\text { Arabian Gulf } \\
\text { (off Saudi } \\
\text { Arabia) }\end{array}$ & $\begin{array}{l}8-10 \times 14-18 \\
\quad(9 \times 16)\end{array}$ & $\begin{array}{l}4.0-5.0(4.5) \\
\text { diameter }\end{array}$ & $\begin{array}{c}\text { SP: arched } \\
\text { V: equal, with rounded } \\
\text { ends } \\
\text { PC: spherical }\end{array}$ & $\begin{array}{l}\text { Abdel-Baki et al. } \\
2015\end{array}$ \\
\hline $\begin{array}{l}\text { C. intexua } \\
\text { Meglitsch, } 1960\end{array}$ & $\begin{array}{l}\text { Jordanidia solandri } \\
\text { Cuvier } \\
\text { Plagiogenion rubiginosus } \\
\text { (Hutton) }\end{array}$ & $\begin{array}{l}\text { New Zealand } \\
\text { (Pacific Ocean) }\end{array}$ & $\begin{array}{c}3.4-5.4 \times \\
9.3-20.1 \\
(4.4 \times 15.4)\end{array}$ & $\begin{array}{l}1.2-2.2(1.8) \\
\text { diameter }\end{array}$ & $\begin{array}{l}\text { SP: slightly curved } \\
\text { V: equal } \\
\text { PC: spherical }\end{array}$ & Eiras 2006 \\
\hline $\begin{array}{l}\text { C. koieae } \\
\text { Gunter, Burger et } \\
\text { Adlard, } 2010\end{array}$ & Sphyraena forsteri Cuvier & $\begin{array}{l}\text { Lizard Island, } \\
\text { Australia }\end{array}$ & $\begin{array}{c}4.9-6.7 \times \\
28.6-41.2 \\
(5.5 \times 36.7)\end{array}$ & $\begin{aligned} 2.5-2.9 & \times 2.3-2.9 \\
(2.8 & \times 2.6)\end{aligned}$ & $\begin{array}{l}\text { SP: crescent-shaped } \\
\text { V: equal }\end{array}$ & Gunter et al. 2010 \\
\hline $\begin{array}{l}\text { C. milleri } \\
\text { Gunter, Whipps et } \\
\text { Adlard, } 2009\end{array}$ & $\begin{array}{l}\text { Lutjanus fulviflamma } \\
\text { (Forsskål) }\end{array}$ & $\begin{array}{l}\text { Lizard Island } \\
\text { (Australia) }\end{array}$ & $\begin{array}{c}4.1-5.4 \times \\
11.4-20.9 \\
(4.7 \times 16.4)\end{array}$ & $\begin{array}{l}1.3-2.0 \times \\
1.1-2.0 \\
(1.6 \times 1.5)\end{array}$ & $\begin{array}{l}\text { SP: slightly crescent } \\
\text { V: unequal }\end{array}$ & Gunter et al. 2009 \\
\hline $\begin{array}{l}\text { C. pantherini } \\
\text { Gunter, Burger et } \\
\text { Adlard, } 2010\end{array}$ & $\begin{array}{l}\text { Bothus pantherinus } \\
\text { (Rüppell) }\end{array}$ & $\begin{array}{l}\text { Lizard Island, } \\
\text { Australia }\end{array}$ & $\begin{array}{c}7.3-9.1 \times \\
17.9-24.6 \\
(8.1 \times 21.6)\end{array}$ & $\begin{array}{c}2.3 \times 2.2 \\
(1.8-2.6 \times \\
1.7-2.6)\end{array}$ & $\begin{array}{l}\text { SP: crescent-shaped } \\
\text { V: equal }\end{array}$ & Gunter et al. 2010 \\
\hline $\begin{array}{l}\text { C. sprenti } \\
\text { Moser, Kent et } \\
\text { Dennis, } 1989\end{array}$ & $\begin{array}{l}\text { Chaetodon aureofasciatus } \\
\text { Macleav }\end{array}$ & $\begin{array}{l}\text { Australia } \\
\text { (Coral Sea) }\end{array}$ & $\begin{array}{l}4-8 \times 14-23 \\
(5.7 \times 16.3)\end{array}$ & $\begin{array}{l}2-3(2.4) \\
\text { diameter }\end{array}$ & $\begin{array}{c}\text { SP: stubby } \\
\text { V: equal, slightly } \\
\text { tapered with rounded } \\
\text { ends }\end{array}$ & Eiras 2006 \\
\hline $\begin{array}{l}\text { C. subtilis } \\
\text { Meglitsch, } 1960\end{array}$ & $\begin{array}{l}\text { Coelorhynchus australis } \\
\text { (Richardson) }\end{array}$ & $\begin{array}{l}\text { New Zealand } \\
\text { (Pacific Ocean) }\end{array}$ & $\begin{array}{c}3.4-4.5 \times \\
15.7-26 \\
(3.9 \times 21.5)\end{array}$ & $\begin{array}{c}1.5-2 \\
(1.8) \text { diameter }\end{array}$ & $\begin{array}{c}\text { SP: slender } \\
\text { V: equal or somewhat } \\
\text { unequal }\end{array}$ & Eiras 2006 \\
\hline $\begin{array}{l}\text { Ceratomyxa bohari } \\
\text { sp. n. }\end{array}$ & $\begin{array}{l}\text { Lutjanus bohar } \\
\text { Forsskål }\end{array}$ & $\begin{array}{l}\text { Saudi Arabia } \\
\text { (Red Sea) }\end{array}$ & $\begin{array}{c}3-4 \times 16-19 \\
(3.5 \times 17)\end{array}$ & $\begin{array}{l}1-2(1.6) \\
\text { diameter }\end{array}$ & $\begin{array}{c}\text { SP: slender shape } \\
\text { V: unequal } \\
\text { PC: spherical }\end{array}$ & Present study \\
\hline
\end{tabular}

$\mathrm{SP}$ - spores; $\mathrm{PC}$ - polar capsules; $\mathrm{V}$ - valves.

1562 bp was deposited in GenBank database under the accession number KP893567. BLAST search using the obtained SSU rRNA sequence revealed no identical myxosporean sequence deposited in GenBank.

The maximum level of similarity was obtained with myxosporidia belonging to the genus Ceratomyxa. Comparison of the 50 selected sequences of species of Ceratomyxa revealed the percentages of identity varying between 86.2\% with C. heinigerae Gunter, Whipps et Adlard, 2009 and $76.9 \%$ with C. aegyptica Yemmen, Marton, Eszterbauer et Bahri, 2012. The sequence differs from the aligned sequences of Ceratomyxa spp. at 158-310 bp over 1240 nucleotide alignment.

Bayesian inference and maximum parsimony methods yielded trees with similar topology. Ceratomyxa bohari sp. n. was placed at the base of the clade grouping C. choer- odonae Heiniger, Gunter et Adlard, 2008, C. koieae Gunter, Burger et Adlard, 2010, C. heinigerae and C. milleri (Fig. 3).

Type host: Lutjanus bohar Forsskål (Perciformes: Lutjanidae), two-spot red snapper.

Type locality: Red Sea off Jizan city (16 $53^{\circ} 21$ "N; $\left.42^{\circ} 32^{\prime} 3 " E\right)$, Saudi Arabia.

Type material: Syntype spores in $80 \%$ ethanol are deposited in the parasitological collection of the Hungarian Natural History Museum under the number HNHM-70639.

Site of infection: The infection was detected as large numbers of free floating spores in the bile solution. Vegetative stages were not observed.

Prevalence: $19 \%$ (overall prevalence; in 67 out of 360 fish examined).

E t y m o log y: The specific name is given after the Arabic common name of the fish host 'bohar'. 


\section{DISCUSSION}

The present species exhibits some morphometric similarities with other members of the genus Ceratomyxa that parasitise fish from different families and different geographical regions (Table 1). Despite the similarity of these species, they differ from Ceratomyxa bohari sp. n. in several characteristics. Ceratomyxa choleospora Landsberg, 1993 differs in having more crescentic and slightly larger spores $(4-5 \mu \mathrm{m} \times 15-23 \mu \mathrm{m} v s$ 3-4 $\mu \mathrm{m} \times 16-19 \mu \mathrm{m})$, equal shell valves and a sporoplasm filling the entire extracapsular space. Ceratomyxa dissostichi Brickle, Kalavati et MacKenzie, 2001 is distinguished from the present species by having equal valves, triangular intercapsular thickening and a larger ellipsoidal polar capsule, compared to the rounded ones in our species $(2.3-3.6 \mu \mathrm{m} v \mathrm{~s}$ 1-2 $\mu \mathrm{m})$. Spores of Ceratomyxa intexua Meglitsch, 1960 can be readily distinguished from the present species by its equal valves that terminate in narrow tips with straight posterior margins and a wide range of spore thicknesses

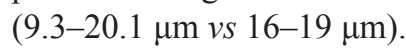

Similarly, Ceratomyxa sprenti Moser, Kent et Dennis, 1989 has quite long spores (4-8 $\mu \mathrm{m} v s 3-4 \mu \mathrm{m})$ with straight anterior and posterior margins and equal shell valves, whereas Ceratomyxa subtilis Meglitsch, 1960 has thicker spores [21.5 $\mu \mathrm{m}(15.7-26 \mu \mathrm{m})$ vs $17 \mu \mathrm{m}(16-19 \mu \mathrm{m})]$ with equal valves. Ceratomyxa anko Freeman, Yokoyama et Ogawa, 2008 is quite different to our species in all its body dimensions $[(11 \mu \mathrm{m}(10-12 \mu \mathrm{m}) \times 42 \mu \mathrm{m}(37-47 \mu \mathrm{m}) v \mathrm{~s}$ $3.5 \mu \mathrm{m}(3-4 \mu \mathrm{m}) \times 17 \mu \mathrm{m}(16-19 \mu \mathrm{m})]$. Also, C. choerodonae differ in having lager spores with equal valves $(5 \mu \mathrm{m}$ $\times 21 \mu \mathrm{m} v \mathrm{~s} 3.5 \mu \mathrm{m} \times 17 \mu \mathrm{m})$.

Ceratomyxa heinigerae can be differentiated by their longer and thicker spores $(5.6 \mu \mathrm{m} \times 24.0 \mu \mathrm{m} v s 3.5 \mu \mathrm{m}$ $\times 17 \mu \mathrm{m})$. Ceratomyxa milleri differs in having thicker spores $(4.7 \mu \mathrm{m} v s 3.5 \mu \mathrm{m})$ with straight posterior margins and subspherical polar capsules. Ceratomyxa koieae differs in having quite larger spores with equal valves $(5.5 \mu \mathrm{m}$ $\times 36.7 \mu \mathrm{m} v s 3.5 \mu \mathrm{m} \times 17.0 \mu \mathrm{m})$. Ceratomyxa pantherini Gunter, Burger et Adlard, 2010 has rather longer and thicker spores $(7.3-9.1 \mu \mathrm{m} \times 17.9-24.6 \mu \mathrm{m} v s 3-4 \mu \mathrm{m} \times$ 16-19 $\mu \mathrm{m})$.

It is worth mentioning that, recently, our research group described three ceratomyxan species from fishes in the Arabian Gulf off Saudi Arabia. These species are Ceratomyxa arabica Al-Qahtani, Mansour, Al-Quraishy et Abdel-Baki, 2015, Ceratomyxa hamour Mansour, Al-Qahtani, Al-Quraishy et Abdel-Baki, 2015 and Ceratomyxa husseini Abdel-Baki, Mansour, Al-Qahtani, Al Omar et AlQuraishy, 2015, but all of these differ from this new species in having longer spores $(7-9 \mu \mathrm{m}, 6-8 \mu \mathrm{m}, 8-10 \mu \mathrm{m}$, respectively vs 3-4 $\mu \mathrm{m}$ ) (see Abdel-Baki et al. 2015, Al-Qahtani et al. 2015, Mansour et al. 2015).

Ceratomyxa bohari was present all year round with a maximum prevalence in autumn $(31 \%)$ and a minimum prevalence in winter $(12 \%)$. In general, many factors are involved in seasonal fluctuations of myxosporeans, including temperature, endogenous cycles of the parasites and the availability of susceptible hosts (Foott and Hedrick 1987, Alvarez-Pellitero and Sitjà-Bobadilla 1993, Alvarez-Pellitero et al. 1995, Yokoyama and Fukuda 2001). Additionally, the seasonal variation in prevalence of ceratomyxan parasites could be attributable to the variable condition of bile secretion at each sampling period (Yokoyama and Fukuda 2001).

Phylogenetic analysis based on maximum likelihood, maximum parsimony and Bayesian inference methods clusters $C$. bohari within the clade grouping the majority of species of Ceratomyxa within the marine lineage. Recently, a large phylogenetic reconstruction of Ceratomyxa resulted in distinction of five subclades (Fiala et al. 2015). The newly identified species clusters within subclade $\mathrm{E}$ of Fiala et al. (2015), which contains the highest number of species analysed.

The new species appears at the base of a well-supported clade grouping $C$. choerodonae, $C$. koieae, $C$. heinigerae and C. mulleri Gunter, Whipps et Adlard, 2009. All these species of Ceratomyxa were reported from fishes off Australia. Of them, C. milleri was described in the gall bladder of dory snapper, Lutjanus fulviflamma (Forsskål) Lutjanidae.

The obtained sequence has at least $8 \%$ divergence from other deposited sequences of identified species. The least sequence divergence was $7.9 \%$ with $C$. heinigrae from Choerodon cephalotes (Castelnau) (Perciformes: Labridae) in Australia (Gunter et al. 2009). Sequence divergence with the three recently identified species of Ceratomyxa in the Arabian Gulf, C. arabica, C. hamour and C. husseini, was $8.5 \%, 15.4 \%$ and $9.6 \%$, respectively. These data support validity of the new species from $L$. bohar in the Red Sea.

Acknowledgements. We extend our appreciation to the Dean of Scientific Research, King Saud University, for funding the work through the research group project number PRG-1436-02.

\section{REFERENCES}

Abdel-Baki A.S., Mansour L., Al-Qahtani H.A., Al Omar S.Y., Al-Quraishy S. 2015: Morphology, seasonality and phylogenetic relationships of Ceratomyxa husseini n. sp. from the gall-bladder of Cephalopholis hemistiktos (Ruppell) (Perciformes: Serranidae) in the Arabian Gulf off Saudi Arabia. Syst. Parasitol. 91: 91-99.

Abdel-Ghaffar F., Ali M. A., Al Quraishy S., Al Rasheid K., Al Farraj S., Abdel-Baki A.S., Bashtar A. R. 2008: Four new species of Ceratomyxa Thelohan 1892 (Myxozoa:
Myxosporea: Ceratomyxidae) infecting the gallbladder of some Red Sea fishes. Parasitol. Res. 103: 559-565.

Ali M., Abdel-Baki A.S., Sakran T. 2008: Myxidium elmatboulii n. sp. and Ceratomyxa ghaffari n. sp. (Myxozoa:Myxosporea) Parasitic in the Gallbladder of the Red Sea Houndfish Tylosuruschoram (Rüppell, 1837) (Teleostei: Belonidae) from the Red Sea, Egypt. Acta Protozool. 45: 97-103.

Al-Qhhtani H.A., Mansour L., Al-Quraishy S., Abdel-BaKI A.S. 2015: Morphology, phylogeny and seasonal prevalence of Ceratomyxa arabica n. sp. (Myxozoa: Myxosporea) infecting 
the gallbladder of Acanthopagrus bifasciatus (Pisces: Sparidae) from the Arabian Gulf, Saudi Arabia. Parasitol. Res. 114 465-471.

Altschul S.F., Madden T.L., Schaffer A.A., Zhang J., Zhang Z., Miller W., Lipman D.J. 1997: Gapped BLAST and PSI-BLAST: a new generation of protein database search programs. Nucl. Acids Res. 25: 3389-3402.

Alvarez-Pellitero P., Sitjà-Bobadilla A. 1993: Pathology of Myxosporea in marine fish culture. Dis. Aquat. Organ. 17: 229-238.

Alvarez-Pellitero P., Sitjà-Bobadilla A., Franco-Sierra A., Palenzuela O. 1995: Protozoan parasites of gilthead sea bream, Sparus aurata L., from different culture systems in Spain. J. Fish Dis. 18: 105-115.

Atkinson S.D., Foott J.S., Bartholomew J.L. 2014: Erection of Ceratonova n. gen. (Myxosporea: Ceratomyxidae) to encompass freshwater species C. gasterostea n. sp. from threespine stickleback (Gasterosteus aculeatus) and C. shasta n. comb. from salmonid fishes. J. Parasitol. 100: 640-645.

Azevedo C., Rocha S., Matos P., Matos E., Oliveira E., AlQuraishy S., CaSal G. 2014: Morphology and phylogeny of Henneguya jocu n. sp. (Myxosporea, Myxobolidae), infecting the gills of the marine fish Lutjanus jocu. Eur. J. Protistol. 50: 185-193.

Brickle P., Kalavati C., MacKenzie K. 2001: Two new species of myxozoan parasites (Myxosporea, Bivalvulida) from toothfish Dissostichus eleginoides Smitt, 1898 (Pisces, Nototheniidae). Acta Parasitol. 46: 250-253.

Eiras J.C. 2006: Synopsis of the species of Ceratomyxa Thélohan, 1892 (Myxozoa: Myxosporea: Ceratomyxidae). Syst. Parasitol. 65: 49-71.

Fiala I. 2006. The phylogeny of Myxosporea (Myxozoa) based on small subunit ribosomal RNA gene analysis. Int. J. Parasitol. 36 $1521-1534$.

Fiala I., HlavničKová M., Kodádková A., Freeman M.A., BARtošovÁ-Sojková P., AtKinson S.D. 2015: Evolutionary origin of Ceratonova shasta and phylogeny of the marine myxosporean lineage. Mol. Phylogenet. Evol. 86: 75-89.

Foott J.S., HedRICK R.P. 1987: Seasonal occurrence of the infectious stage of proliferative kidney disease (PKD) and resistance of rainbow trout, Salmo gairdneri Richardson, to reinfection. J. Fish Biol. 30: 477-483.

Freeman M.A., Yokoyama H., Ogawa K. 2008: Description and phylogeny of Ceratomyxa anko sp $\mathrm{n}$. and Zschokkella lophii $\mathrm{sp}$ n. from the Japanese anglerfish, Lophius litulon (Jordan). J. Fish Dis. 31: 921-930.

Gunter N.L., Burger M.A., Adlard R.D. 2010: Morphometric and molecular characterisation of four new Ceratomyxa species (Myxosporea: Bivalvulida: Ceratomyxidae) from fishes off Lizard Island, Australia. Folia Parasitol. 57: 1-10.

Gunter N.L., Whipps C.M., Adlard R.D. 2009: Ceratomyxa (Myxozoa: Bivalvulida): robust taxon or genus of convenience? Int. J. Parasitol. 39: 1395-1405.

HALL T.A. 1999: Bioedit: a user-friendly biological sequence alignment editor and analysis program for windows 95/98/NT. Nucl. Acids Symp. 41: 95-98.

Heiniger H., Gunter N.L., Adlard R.D. 2008: Relationships between four novel ceratomyxid parasites from the gall bladders of labrid fishes from Heron Island, Queensland, Australia. Parasitol. Int. 57: 158-165.
Holzer A.S., Bartošová P., Pecková H., Tyml T., Atkinson S., Bartholomew J., Sipos D., Eszterbauer E., Dyková I. 2013. 'Who's who' in renal sphaerosporids (Bivalvulida: Myxozoa) from common carp, Prussian carp and goldfish - molecular identification of cryptic species, blood stages and new members of Sphaerospora sensu stricto. Parasitology 140: 46-60.

KimuRA M. 1980: A simple method for estimating evolutionary rates of base substitutions through comparative studies of nucleotide sequences. J. Mol. Evol. 16: 111-120.

LANDSBERG J.H. 1993: Myxosporean parasites of common snook in Florida. J. Aquat. Anim. Hlth. 5: 102-109.

Larkin M.A., Blackshields G., Brown N.P., Chenna R., McGettigan P.A., McWilliam H., Valentin F., Wallace I.M., Wilm A., Lopez R., Thompson J.D., Gibson T.J., HigGINS D.G. 2007: Clustal W and Clustal X version 2.0. Bioinformatics 23: 2947-2948.

Lom J., Arthur J. R. 1989: A guideline for the preparation of species descriptions in Myxosporea. J. Fish Dis. 12: 151-156.

Mansour L., Al-Qahtani H.A., Al-Quraishy S., Abdel-BaKI A.S. 2015: Molecular and morphometric characteristics of Ceratomyxa hamour n. sp. (Myxosporea: Bivalvulida) infecting the gallbladder of the orange-spotted grouper Epinephelus coioides from the Arabian Gulf, Saudi Arabia. J. Eukaryot. Microbiol. 62: 95-101.

Mansour L., Thabet A., Chourabi K., Harrath A.H., Gtari M., Al Omar S.Y., Ben Hassine O.K. 2013. Kudoa azevedoi n. sp. (Myxozoa, Multivalvulida) from the oocytes of the Atlantic horse mackerel Trachurus trachurus (Perciformes, Carangidae) in Tunisian coasts. Parasitol. Res. 112: 1737-1747.

Miller T.L., Adlard R. D. 2013: Unicapsula species (Myxosporea: Trilosporidae) of Australian marine fishes, including the description of Unicapsula andersenae n. sp. in five teleost families off Queensland, Australia. Parasitol. Res. 112: 2945-2957.

PosadA D. 2008:. jModelTest: phylogenetic model averaging. Mol. Biol. Evol. 25: 1253-1256.

Reiczigel J., Rozsa L., Reiczigel A. 2014: Quantitative Parasitology (QPweb). http://www2.univet.hu/qpweb/, 12/2014.

Rocha S., Casal G., Rangel L., Castro R., Severino R., Azevedo C., Santos M.J. 2015: Ultrastructure and phylogeny of Ceratomyxa auratae n. sp. (Myxosporea: Ceratomyxidae), a parasite infecting the gilthead seabream Sparus aurata (Teleostei: Sparidae). Parasitol. Int. 64: 305-313.

RonQuist F., HuELSENBeck J.P. 2003: MRBAYES 3: Bayesian phylogenetic inference under mixed models. Bioinformatics 19: 1572-1574.

Tamura K., Peterson D., Peterson N., Stecher G., Nei M., Kumar S. 2011: MEGA5: Molecular Evolutionary Genetics Analysis using maximum likelihood, evolutionary distance, and maximum parsimony methods. Mol. Biol. Evol. 28: 2731-2739.

Whipps C.M., Adlard R.D., Bryant M.S., Kent M.L. 2003: Two unusual myxozoans, Kudoa quadricornis n. sp. (Multivalvulida) from the muscle of goldspotted trevally (Carangoides fulvoguttatus) and Kudoa permulticapsula n. sp. (Multivalvulida) from the muscle of Spanish mackerel (Scomberomorus commerson) from the Great Barrier Reef, Australia. J. Parasitol. 89: $168-173$.

Yokoyama H., Fukuda Y. 2001: Ceratomyxa seriolae n. sp. and C. buri n. sp. (Myxozoa: Myxosporea) from the gall-bladder of cultured yellowtail Seriola quinqueradiata. Syst. Parasitol. 48: $125-130$. 